\section{THE EFFECT OF PARTICLE SIZE OF EMPTY FRUIT BUNCH AND RATIO OF BIOSLUDGE OF PULP AND PAPER ON BIOCHEMICAL CHANGES IN COMPOSTING PROCESS}

Desrihastutia, Ida Idayu Muhamada*, Roshanida Abdul Rahmana, Gading Sahyogab, Abdul Gafurb

aschool of Chemical and Energy Engineering, Faculty of Engineering, Universiti Teknologi Malaysia, 81310 UTM Johor Bahru, Johor, Malaysia

bRiau Andalan Pulp and Paper Industry, 28300, Pelalawan, Riau, Indonesia
Article history

Received

19 August 2018

Received in revised form

28 November 2018

Accepted

1 January 2019

Published online

18 February 2019

*Corresponding author idaidayu@utm.my

\section{Graphical Abstract}

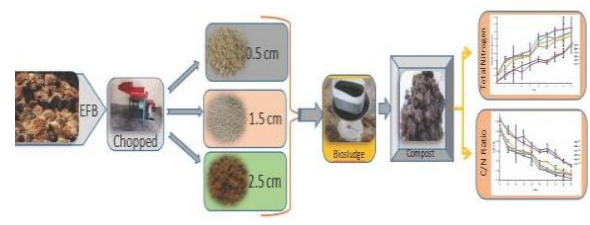

\begin{abstract}
The abundance of empty fruit bunches (EFB) is a result of many palm oil industries increasing their crude palm oil production. Composting is a good, environmentally friendly alternative to overcome EFB. Two different ratios of EFB with biosludge of pulp and paper of $1: 1$ and $3: 2$, respectively, were used in this composting. The particle size of EFB was set into three different sizes of $0.5 ; 1.5$ and $2.5 \mathrm{~cm}$. The best treatment that was obtained from this study was $\mathrm{SR}_{4}$ where the EFB particle size was $1.5 \mathrm{~cm}$, and the ratio between EFB and biosludge of pulp and paper was $3: 2$, respectively. The nitrogen value of $\mathrm{SR}_{4}$ increased from $1.41 \%$ to $2.71 \%$, and $\mathrm{C} / \mathrm{N}$ ratio decreased from 36.74 to 12.17 in 90 days. The population peak of bacteria of SR4 in the thermopilic phase achieved about $33.67 \times 10^{10} \mathrm{cfu} / \mathrm{g}$. These two treatment combinations had shown an increase in EFB composting efficiency.
\end{abstract}

Keywords: Empty fruit bunch, biosludge of pulp and paper, particle size, composting

\begin{abstract}
Abstrak
Kelimpahan tandan buah kosong (EFB) adalah sebuah akibat yang timbul kerana banyak industri minyak sawit meningkatkan pengeluaran minyak sawit mentah mereka. Pengkomposan adalah sebuah alternatif yang baik untuk mengatasi EFB dengan mesra alam. Dua nisbah yang berbeza antara EFB dengan bioenapcemar pulpa dan kertas telah disusun dalam pengkomposan ini dan masing-masing terdiri daripada $1: 1$ dan $3: 2$. Saiz EFB telah ditetapkan kepada tiga saiz berbeza yang terdiri daripada $0.5 ; 1.5$ dan $2.5 \mathrm{~cm}$. Rawatan terbaik yang diperoleh dalam kajian ini adalah $\mathrm{SR}_{4}$ di mana saiz EFB adalah $1.5 \mathrm{~cm}$, dan nisbah antara EFB dan bioenapcemar pulpa dan kertas masing-masing adalah $3: 2$. Nilai nitrogen $\mathrm{SR}_{4}$ meningkat dari $1.41 \%$ kepada $2.71 \%$, dan nisbah $\mathrm{C} / \mathrm{N}$ menurun dari 36.74 hingga 12.71 pada 90 hari. Puncak bakteria $\mathrm{SR}_{4}$ dalam fasa termopilik mencapai $33.67 \mathrm{x}$ $1010 \mathrm{cfu} / \mathrm{g}$. Dua kombinasi rawatan ini telah menunjukkan peningkatan dalam kecekapan pengkomposan EFB.
\end{abstract}

Kata kunci: Tandan buah kosong, bioenapcemar pulpa dan kertas, saiz zarah, pengkomposan 


\subsection{INTRODUCTION}

Indonesia is the biggest crude palm oil producer in the world [1]. Nowadays, the palm oil industries are more enterprising enhancing the production of crude palm oil either by expanding the plantation area or by improving plantation management. The abundance of palm oil waste appears to be a consequence of production enhancement activities. Every one ton of crude palm oil (CPO) requires 5.8 tons of fresh fruit bunch (FFB) [1], and leaves behind $22.5 \%$ of empty fruit bunch (EFB) [2]. Some palm oil mills in Indonesia are able to process approximately $1,000-1,300$ tons of FFB per day, or 30,000-35,400 tons per month with a production capacity of 60 tons per hour, and duration of the milling process is 20 hours per day [3], leaving behind an estimated EFB of around 225-292.5 tons per day, or 6,750-8,775 tons per month per mill. Commonly, each palm oil industry has more than one processing plant, whilst there are 1,601 of palm oil industries in Indonesia [4]. Therefore, safe management strategy for disposing agricultural waste is still a global concern in the palm oil industry.

Most of the palm oil industries utilize the EFB for mulching media. The discharged EFB is estimated to be around 40-70 tons per ha [5]. The mulching strategy can hold moisture and prevent erosion of soil [6]. However, prolonged application in high quantities can reduce soil nutrient and increase soil toxicity due to its oil content. In addition, the EFB application directly to the soil will take a longer degradation time, and it also requires high transportation and distribution costs $[7,8]$.

Composting is one of the environmentally friendly alternatives to overcome the waste problem. Norhasmillah et al. [9] estimated that complete degradation of EFB in the composting method could save time by about $89 \%$ compared to the mulching method [9]. The principal process of composting is to convert organic matter into a more stable form resembling humus. This conversion process involves microorganism activity as decomposer. Various attempts have been tried in EFB composting to improve EFB compost quality. Experiments have been widely developed both in the supply aspect of various nitrogen sources such as poultry litter, chicken manure, goat dung and cow dung, and in the addition of microbial sources from palm oil mill effluent (POME), decanter cake slurry and multi fungal $[10,11,12,13,14,15,16,17]$.

Additionally, compost material size can be modified to optimize the composting process. Bueno et al. [18] confirmed that particle size is a parameter of natural substrate, and it is one of factors controlling the composting process [18]. A small substrate size provides a large surface area for microorganism activity, whereas a big substrate size creates a small surface area. Most of the microbial activity in the degradation process occurs on the particle surface [19]. Moreover, Suhaimi and Ong [8] stated that the small material size had a lot of pores space, so that evaporation occurred in the material and caused the moisture content of the material to reduce. Therefore, wastewater from the pulp and paper industry can be used in the EFB composting as a substitute for water. This wastewater originates from the biological wastewater treatment plant, and is known as biosludge. The biosludge also contains several microorganisms consisting of bacteria, protozoa, alga, fungi, and rotifer [20]. These microorganisms function as degrading organic matters. The use of pulp and paper biosludge is expected to optimize EFB composting process. However, adding the proper proportion of biosludge of pulp and paper should be considered, because the quantity of moisture content, either too much or too little, can interfere in the efficiency of composting [21]. Hence, this study investigates the effect of different EFB sizes with different ratio of biosludge of pulp and paper on EFB composting.

\subsection{METHODOLOGY}

\subsection{Raw Material Collection}

EFB taken from the palm oil mill at PT. Asian Agri, Pangkalan Kerinci, Pelalawan, Riau, Indonesia, was chopped into three different sizes consisting of 0.5 $\mathrm{cm} ; 1.5 \mathrm{~cm}$ and $2.5 \mathrm{~cm}$ (Table 1). Next, the chopped EFB was separated manually using a wiremesh sieve. Meanwhile, biosludge of pulp and paper was collected from the pulp and paper industry at PT. Riau Andalan Pulp and Paper, Pangkalan Kerinci, Pelalawan, Riau, Indonesia.

Table 1 Treatment combination between EFB with biosludge of pulp and paper

\begin{tabular}{lll}
\hline Code & \multicolumn{1}{c}{ EFB Size } & Ratio EFB : Biosludge \\
\hline $\mathrm{SR}_{1}$ & $0.5 \mathrm{~cm}$ & $1: 1$ \\
$\mathrm{SR}_{2}$ & $0.5 \mathrm{~cm}$ & $3: 2$ \\
$\mathrm{SR}_{3}$ & $1.5 \mathrm{~cm}$ & $1: 1$ \\
$\mathrm{SR}_{4}$ & $1.5 \mathrm{~cm}$ & $3: 2$ \\
$\mathrm{SR}_{5}$ & $2.5 \mathrm{~cm}$ & $1: 1$ \\
$\mathrm{SR}_{6}$ & $2.5 \mathrm{~cm}$ & $3: 2$ \\
\hline
\end{tabular}

\subsection{Construction and Composting Procedure}

A composter was designed using a plastic container of $50 \mathrm{~L}$ capacity, $38 \mathrm{~cm}$ diameter and 40 $\mathrm{cm}$ height (Figure 1). On the inside of the composter, perforated pipes, with diameter holes of about $0.7 \mathrm{~cm}$, were installed at the top, bottom and middle. At the base of the composter, a few holes were made to drain leachate during composting. Next, compost material of EFB mixed with biosludge of pulp and paper in two different ratios were placed in the composter. Subsequently, the compost material was closed and put under a roof. Turning process was conducted every four days. The composting duration lasted 90 days with three replications. 


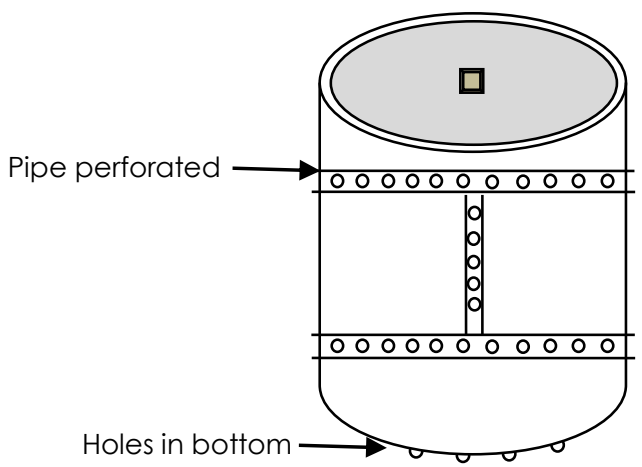

Figure 1 Design for composter

\subsection{Physical Analysis}

Physical observation was conducted on EFB, biosludge of pulp and paper and the resulted compost. The physical analysis included texture, colour, odour, and temperature. Observation of texture, colour and odour was detected by the finger, visual and smelling methods, respectively. Meanwhile, temperature observation was done during the composting process, and recorded at 09.00-10.00 am using digital measurement (AMT-300, CV. Java Multi Mandiri, Indonesia). Temperature was measured at three different points, and at three different depths.

\subsection{Laboratory Analysis and Sampling}

Laboratory analysis was also carried out on EFB, biosludge of pulp and paper and the resulted compost. On EFB and biosludge of pulp and paper, the analysis of laboratory which was conducted for characterizing these raw materials consisted of moisture content, $\mathrm{pH}$, total organic carbon (TOC), total nitrogen, $\mathrm{C} / \mathrm{N}$ ratio, chemical oxygen demand (COD), and biological oxygen demand (BOD). Meanwhile, the laboratory analysis on compost was done every ten days to determine the nutrient content during the composting process. This analysis comprised of moisture content, bacteria concentration, total nitrogen concentration, TOC and $\mathrm{C} / \mathrm{N}$ ratio. Sampling for compost was collected randomly around $500 \mathrm{~g}$ at three different points.

The $\mathrm{pH}$ analysis was measured using a digital $\mathrm{pH}$ meter (EUTECH PC 510, USA). The dilution extract used ratio of 1 : 10 of weight. Furthermore, $5 \mathrm{~g}$ of wet samples were dried at $105^{\circ} \mathrm{C}$ for 7 hours to determine moisture content. Calculation of moisture content follows equation 1.

$$
M C \equiv \frac{(w+v) y}{(w+v)+w} \times 100
$$

Where MC is the percentage of moisture content, $\mathrm{W}$ is the weight of crucible (g), $v$ is the initial weight of sample (g), and $y$ is the weight of oven dried sample (g).

Measurement of total organic carbon and total nitrogen was determined using inductively coupled plasma (OES Optima 4300DV, Perkin Elmer, USA). Meanwhile, COD and BOD were examined using the APHA method [22]. Bacteria colonies were counted using a colony counter machine (Funke Gerber colony star 8500, Funke-Dr.N. Gerber Labortechnik $\mathrm{GmbH}$, Germany). The bacteria were incubated on the nutrient agar for 24 hours. Microbial calculation follows equation 2.

$$
M C T=\frac{\text { Total } / \text { Petridish }}{1 \text { gsample }} \times \frac{1}{D f}
$$

Where MCT is total microbes concentration (cfu/g) and Df is dilution factor.

\subsection{Statistical Analysis}

The influence of each treatment, and their interactions was analyzed using Two-way ANOVA $(p<0.05)$. Mean values were compared using Duncan multiple range test. Average values were reported as the standard error. Pearson correlation analysis $(p<0.01)$ was not only used to determine the relationship strength of the treatment, but also to find the magnitude of the treatment influence.

\subsection{RESULTS AND DISCUSSION}

\subsection{Raw Material Characterization}

The properties of EFB and biosludge pulp and paper as raw material in the composting composition are shown in Table 2. The characteristic of EFB was strict and rough fibrous, whereas the biosludge of pulp and paper was thick liquid, colloidal slurry and brown in colour. The moisture content of biosludge of pulp and paper was higher than EFB. Therefore, mixing biosludge of pulp and paper with EFB balanced moisture content in starting the composting. The nitrogen value of EFB was lower than biosludge of pulp and paper. The addition of biosludge of pulp and paper into EFB upgraded the nitrogen value of $E F B$, and brought down the $C / N$ ratio of $E F B$ in the initial stage of composting.

COD and BOD in biosludge of pulp and paper were $31,000 \mathrm{mg} / \mathrm{l}$ and $4,650 \mathrm{mg} / \mathrm{l}$, respectively. These values indicated that biosludge of pulp and paper had high organic matter. In comparison, the COD value in this study was lower than the anaerobic palm oil mill effluent that was obtained by Ahmad et al. [23] where the COD valued 40,563 $\mathrm{mg} / \mathrm{l}$ [23]. Meantime, the BOD value in this study was higher than in Baharuddin et al. [10] which had a range between 1,000-2,600 $\mathrm{mg} / \mathrm{l}$. Although the BOD in the biosludge of pulp and paper had a high value, it could be returned to the soil. This was confirmed by 
Okwute et al. [24] who reported that the wastewater could be reused for land application when the BOD value was below $5000 \mathrm{mg} / \mathrm{l}$ [24].

Table 2 Characterization of EFB and biosludge of pulp and paper

\begin{tabular}{lll}
\hline Parameters & \multicolumn{1}{c}{ EFB } & \multicolumn{1}{c}{$\begin{array}{c}\text { Biosludge of } \\
\text { Pulp and Paper }\end{array}$} \\
\hline Moisture (\%) & $43.00 \pm 2.69$ & $93.70 \pm 2.40$ \\
pH & $6.87 \pm 0.05$ & $7.09 \pm 0.16$ \\
TOC (\%) & $54.59 \pm 0.13$ & $33.30 \pm 0.85$ \\
Total Nitrogen (\%) & $1.02 \pm 0.04$ & $1.21 \pm 0.04$ \\
C/N & $53.57 \pm 2.35$ & $27.66 \pm 1.52$ \\
BOD & - & 4,650 \\
COD & - & 31,000 \\
\hline
\end{tabular}

\subsection{Quality of Compost Product}

Texture of the compost at the beginning of composting was very hard and rigid. After one month of the composting process, the treatment of $\mathrm{SR}_{5}$ and $\mathrm{SR}_{6}$ had begun to brittle and fracture, while other treatments had started to break down. At the end of composting, the texture of all composts had crumbled. Yeoh et al. [17] found that the mixture of $E F B, P O M E$ and some fungal resulted in fragile compost texture at the end of composting.

During the composting process, compost material underwent discolouration. Monitoring of odour and colour during the composting was easily supervised as an indicator of compost maturation process [25]. At the beginning of composting, all compost materials were light brown. At 17 days of composting, the compost colour of $\mathrm{SR}_{1}, \mathrm{SR}_{2}, \mathrm{SR}_{3}$ and $\mathrm{SR}_{4}$ began to change to dark brown, whereas the compost colour of the other treatments was still brown. The compost colour turned blackish brown after one month of composting. At the end of composting, the colour of all compost was a relatively uniform black. Khalil et al. [26] stated that the compost colour gradually changed from black to brownies black, and it could be an indication of compost maturity [26].

In the first application of biosludge of pulp and paper on EFB, all compost material had a slightly putrid smell. The unpleasant odour was found to have originated from the biosludge of pulp and paper which contained nitrogen. Nakasaki et al. [27] pointed out that ammonia will be released into the atmosphere when raw sludge contains a high percentage of nitrogen [27]. The smell diminished when the compost entered the thermophilic phase. At the end of composting, all compost materials had an earthy smell.

\subsection{Temperature Fluctuation}

Figure 2 shows the changes in temperature during the composting process. Generally, the temperature in all treatments increased quickly within the first 12 hours after mixing biosludge of pulp and paper. This lasted for 3 days, and ranged from $55^{\circ} \mathrm{C}$ to $60^{\circ} \mathrm{C}$. The highest temperature was found in the treatment of $\mathrm{SR}_{4}$ on day 3 which reached $60^{\circ} \mathrm{C}$, the temperature in the treatment of $S R_{1}$ and $S_{2}$ only reached $55^{\circ} \mathrm{C}$. From day 4 to day 23, the temperature decreased gradually, and gained $40^{\circ} \mathrm{C}$ for the treatment of $S_{3}$, $\mathrm{SR}_{4}, \mathrm{SR}_{5}$ and $\mathrm{SR}_{6}$, whereas the treatment of $\mathrm{SR}_{1}$ and $\mathrm{SR}_{2}$ attained it on day 18.

Although the composting temperature exhibited a decline, it was still included in the thermophilic phase. Mokhtari et al. [28] declared that the thermophilic phase of the composting has a temperature above $40^{\circ} \mathrm{C}$ [28]. This phenomenon assumed that there were activities of thermophilic microorganism in degrading organic matter. Another reason is the small particle size of FEB provides a large space for microorganism in decomposing organic matter.

Besides that, the increase in temperature is associated with oxygen consumption of microorganism. Oxygen consumption for microorganism will be more when the temperature increases. Most of the microbial activity in degrading organic matter occurs in the active phase or the thermophilic phase, and that causes high oxygen consumption by the microbes $[29,30,31,32]$.

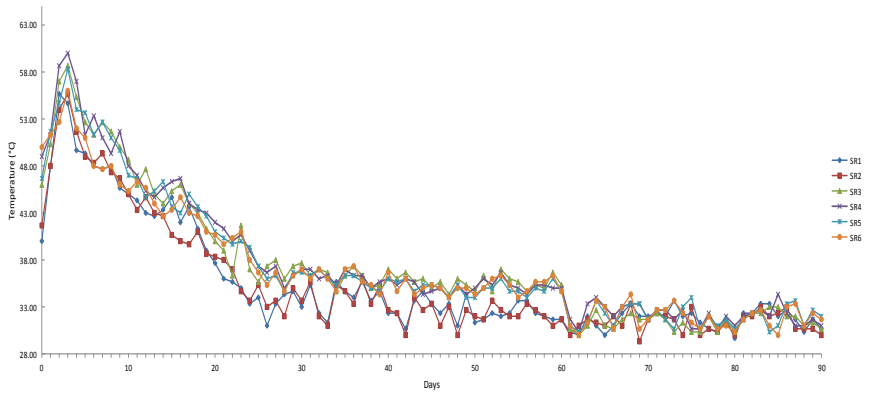

Figure 2 Temperature performance during composting process

Furthermore, the temperature showed piecemeal reduction which indicates the start of the mesophilic phase. The mesophilic phase in the treatment of $S_{3}$, $\mathrm{SR}_{4}, \mathrm{SR}_{5}$ and $\mathrm{SR}_{6}$ started on day 24 , and on day 19 for treatment of $\mathrm{SR}_{1}$ and $\mathrm{SR}_{2}$. Ryckeboer et al. [33] explained that the activity of thermophilic microorganism had subsided which led to a drop in temperature, and mesophilic microorganism forwarded the decomposition process by recolonizing the substrate [33].

A slight decline in temperature was found in the treatment of $\mathrm{SR}_{1}$ and $\mathrm{SR}_{2}$. This occurrence was probably induced by the size of EFB that was rather small $(0.5 \mathrm{~cm})$, which generated compaction of the compost pile. The effect of this condition created a decrease of porosity in the compost pile. Thus, the air flow in the compost pile became slightly constricted. Nonetheless, the turning process on a regular schedule was very useful to repair air flow condition in the compost pile. 
The same support was provided by passive aeration from the perforated pipe in the composter, and this was helpful to expedite air circulation in the compost pile. Ahmad et al. [23] had composted palm frond with a size of 0.2 to $0.5 \mathrm{~cm}$, and led compaction in the compost pile structure, so that the performance of microbial activity and air distribution in compost declined. Tanpanich et al. [34] regarded installation of twin horizontal perforated pipe as a provider of passive aeration in a compost pile was a better oxygen supply during the composting process [34]. At the end of composting, the temperature movement revealed a constant rhythm. This event surmised that the compost had matured. Razali et al. [13] asserted that the stable temperature emitted at the end of the composting, and the decomposition rate of organic matter diminished.

\subsection{Moisture Content Reduction}

Moisture content is one of essential factors to support a successful composting process, because the water is used by the microorganism to decompose organic matter [35]. At the beginning of the composting, the moisture content of $\mathrm{SR}_{1}, \mathrm{SR}_{2}, \mathrm{SR}_{3}, \mathrm{SR}_{4}, \mathrm{SR}_{5}$ and $\mathrm{SR}_{6}$ was $75.9,75.1,73.5,73.5,70.0$, and $60.2 \%$, respectively (see figure 3). These moisture levels were still regarded to be within a favourable range to initiate composting. Gajalakshmi and Abbasi [30] highlighted that the ideal moisture content at the initial stage of composting was $60-70 \%$ and $50-60 \%$ at the later stage of the composting process. Ryckeboer et al. [33] revealed that the performance of microbial activity would slow down when the moisture content had a level below $30 \%$ or above $80 \%$.

In their study, Liang et al. [36] concluded that the minimum requirement of moisture content to increase microbial activity during the composting process was $50 \%$, and the range of moisture content of $60-70 \%$ could provide maximum microbial activity [36]. The moisture content experienced reduction until the end of the composting. Moisture content values achieved were 69.05, 68.00, 64.00, 62.00, 55.28 and $52.00 \%$ of $\mathrm{SR}_{1}, \mathrm{SR}_{2}, \mathrm{SR}_{3}, \mathrm{SR}_{4}, \mathrm{SR}_{5}$ and $\mathrm{SR}_{6}$ respectively. Reduction of moisture content during the composting process can be contributed by the evaporation process, and leachate process from the perforated pipe [37].

Both treatment and composting time had a significant difference on the reduction of moisture content at a significance level of $5 \%$. Duncan multiple range test $(p<0.05)$ described that treatment of $S R_{1}$ and $S R_{2}$ had a low average moisture content reduction compared with treatment of $\mathrm{SR}_{3}, \mathrm{SR}_{4}, \mathrm{SR}_{5}$ and $S R_{6}$. It was suspected that the addition of biosludge of pulp and paper into EFB which had a size of $0.5 \mathrm{~cm}$ created pore spaces of EFB filled with water.

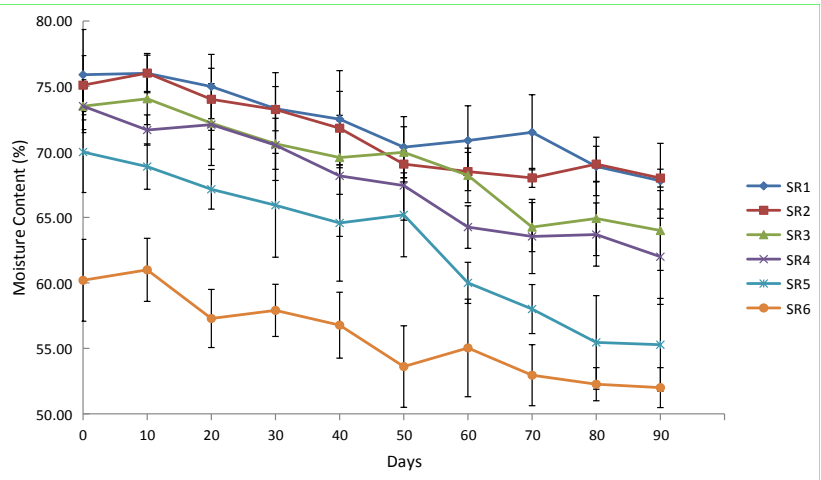

Figure 3 Performance of moisture content reduction

Under the same condition, the turning process should be done routinely to maintain a favourable porosity for microorganism activity in the compost pile. The frequency of the turning process should often be undertaken when the moisture content reaches a high level, so that anaerobic condition in the pile can be minimized. Hong et al. [38] investigated the turning process, which was carried out every 4 days that resulted in a higher moisture content reduction than the turning process carried out every 2 days [38].

\subsection{Bacteria Concentration}

At the beginning of composting, the total bacteria of $\mathrm{SR}_{1}, \mathrm{SR}_{2}, \mathrm{SR}_{3}, \mathrm{SR}_{4}, \mathrm{SR}_{5}$ and $\mathrm{SR}_{6}$ was 13.10, 12.50, 12.93 , $12.23,12.47$ and $12.30 \times 10^{10} \mathrm{cfu} / \mathrm{g}$ respectively (Figure 4). The number of bacteria in this study was higher than in Baharuddin et al.'s [10] who obtained $6 x$ $10^{10} \mathrm{cfu} / \mathrm{g}$. This predicted that biosludge of pulp and paper was not only rich in nutrient, but also in microbes. The bacteria throve swiftly in days 3 and 5 , and achieved 15.10, 23.83, 25.73, 33.67, 29.83 and $30.83 \times 10^{10} \mathrm{cfu} / \mathrm{g}$ of $\mathrm{SR}_{1}, \mathrm{SR}_{2}, \mathrm{SR}_{3}, \mathrm{SR}_{4}, \mathrm{SR}_{5}$ and $\mathrm{SR}_{6}$, respectively. This phenomenon was caused by the small size of EFB that were easily digested by the microbes.

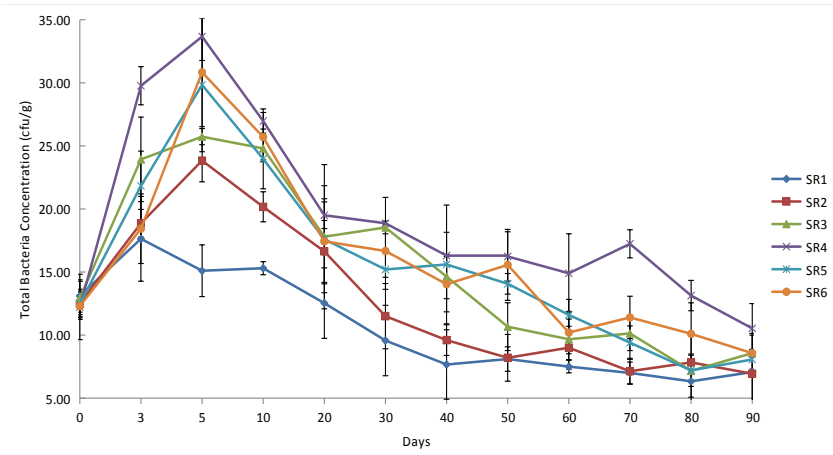

Figure 4 Bacteria concentration during composting process 
In the thermophilic phase of this study, the population of microbe colony was lower than that found in Ahmad et al.'s study [23] which obtained a microbial population of around $66 \times 10^{10} \mathrm{cfu} / \mathrm{g}$, and then subsided to $9.0 \times 10^{10} \mathrm{cfu} / \mathrm{g}$ on 60 days of the composting. The decrease in composting temperature was followed by a decrease in the number of bacteria. The group of bacteria in this phase was suspected to be mesophilic bacteria that were active in degradation activities.

At the end of composting, the number of bacteria of $\mathrm{SR}_{1}, \mathrm{SR}_{2}, \mathrm{SR}_{3}, \mathrm{SR}_{4}, \mathrm{SR}_{5}$ and $\mathrm{SR}_{6}$ was 7.07, 6.93, 8.57, 10.53, 8.07 and $8.57 \times 10^{10} \mathrm{cfu} / \mathrm{g}$, respectively. Thambirajah et al. [14] explained that the changes of temperature of the composting would affect the number of mesophilic and thermophilic bacteria. During the composting process, the highest number of bacteria was found on the treatment of $\mathrm{SR}_{4}$. This phenomenon indicated that the biosludge of pulp and paper ratio was suitable for EFB of $1.5 \mathrm{~cm}$ as bacteria activities thrived at optimal condition. In spite of the fluctuation in bacteria quantity from the beginning to the end of composting, the number of bacteria estimated was still included into the population standard of the composting. Ryckeboer et al. [33] noted that the least quantity of bacteria in the compost was around $10^{8}$ to $10^{13} \mathrm{cfu} / \mathrm{g}$.

\subsection{Total Nitrogen Concentration}

Nitrogen is required by microorganism to establish their new cell material through the process of protein synthesis [39]. Oviasogie et al. [40] and Rasapoor et al., [41] summarized that organic nitrogen was transformed into inorganic nitrogen by microorganism known as the nitrification process [40, 41]. At the beginning of the composting, total nitrogen of $\mathrm{SR}_{1}, \mathrm{SR}_{2}, \mathrm{SR}_{3}, \mathrm{SR}_{4}, \mathrm{SR}_{5}$ and $\mathrm{SR}_{6}$ was 1.25, $1.25,1.38,1.41,1.40$ and $1.39 \%$, respectively. These variations of nitrogen levels were probably caused by ratio differences of biosludge of pulp and paper that were augmented into EFB. Epstein [19] found that the amount of nitrogen in waste varied, and it depended on the type of waste.

The total amount of nitrogen on all treatments increased during the composting process (see Figure 5). Despite this, a decrease in total nitrogen was discovered occasionally occurring on all treatments. This phenomenon was perhaps due to the presence of ammonia in the compost pile as a result of the volatilization process. However, the ammonia volatilization could be minimized because the compost pile had been formed closed.

Moreover, the use of perforated pipe as an air supplier in the passive aeration method had been designed into the composter in order to avoid high ammonia volatilization. Sommer [42] concluded that the composting of cattle deep litter covered by a porous tarpaulin had succeeded in reducing the gaseous emission of nitrogen [42]. The study by Tanpanich et al., [34] proved that the twin horizontal perforated pipe in the compost pile had suppressed loss of nitrogen. Solano et al. [43] suggested that passive aeration system was a suitable system to be used in the composting for small farms because it had the lowest nitrogen loss [43].

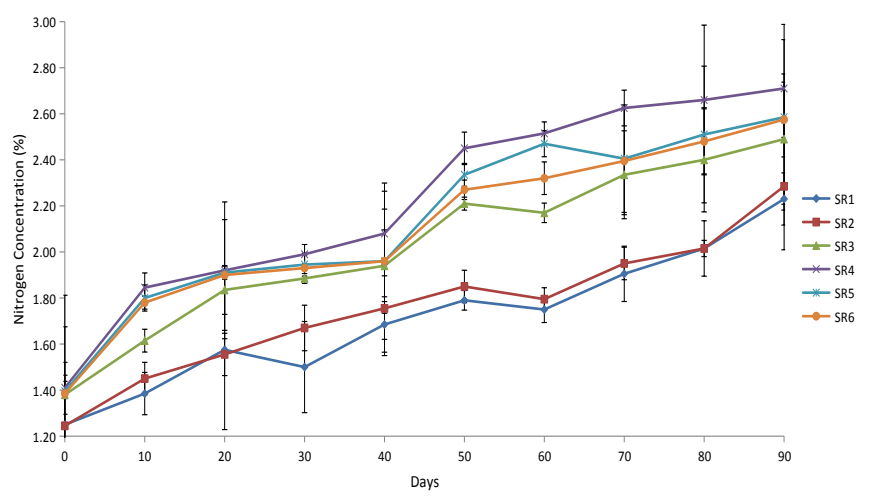

Figure 5 Performance of total nitrogen

At the end of composting, total nitrogen of $\mathrm{SR}_{1}$, $\mathrm{SR}_{2}, \mathrm{SR}_{3}, \mathrm{SR}_{4}, \mathrm{SR}_{5}$ and $\mathrm{SR}_{6}$ was $2.23,2.29,2.49,2.71,2.59$ and $2.58 \%$, respectively. Generally, the nitrogen values in this study exhibited a rise from the beginning of the composting, even though the composting process experienced a curing phase. Caceres et al. [29] observed that the nitrate- $\mathrm{N}$ concentration of solid fraction of the cattle manure increased during the curing phase. Most of the nitrification process takes place in the mesophilic phase that has a temperature between $20^{\circ} \mathrm{C}$ and $35^{\circ} \mathrm{C}$ [44]. Although $\mathrm{SR}_{4}$ (EFB of $1.5 \mathrm{~cm}$ ) had a small surface area compared to $\mathrm{SR}_{1}$ and $\mathrm{SR}_{2}$ (EFB of $0.5 \mathrm{~cm}$ ), it had the highest total nitrogen value. This phenomenon showed that the mixture ratio between EFB and biosludge of pulp and paper (3:2) had created suitable conditions for bacteria growth so that the conversion of organic nitrogen to inorganic nitrogen could run optimally.

The total nitrogen in this study was higher than in Yahya et al.'s [16] study, which carried out composting of EFB with POME and decanter cake slurry, and total nitrogen achieved $2.54 \%$. The same research was undertaken by Baharuddin et al. [10] where EFB composted with POME, had raised total nitrogen from $1.0 \%$ to $2.2 \%$.

\subsection{Total Organic Carbon Concentration}

At the beginning of composting, the concentration of total organic carbon on all treatments was relatively the same, and the range of organic carbon value was approximately 52\% (see Figure 6). Furthermore, organic carbon went down until the end of the composting, and reached 36.5, 36.3, 36.2, $32.8,34.9$ and $35.8 \%$ of $\mathrm{SR}_{1}, \mathrm{SR}_{2}, \mathrm{SR}_{3}, \mathrm{SR}_{4}, \mathrm{SR}_{5}$ and $\mathrm{SR}_{6}$, respectively. The declining carbon content was due to the consumption of carbon by microbes as their energy source, and released heat as an effect of 
their activities. In metabolic activities of microorganism, $69-70 \%$ of organic compound are converted into carbon dioxide and water, whilst the remaining is utilized for their bodies as cellular component [45].

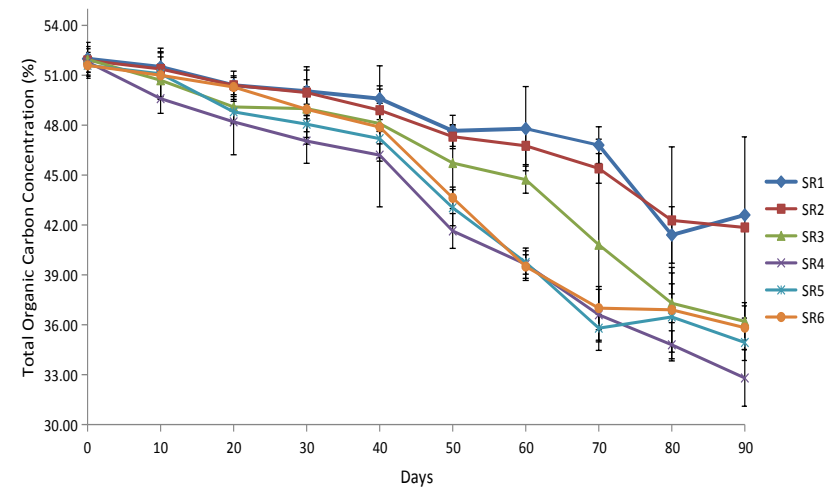

Figure 6 Performance of total organic carbon

Anova analysis $(\alpha<0.05)$ demonstrated that not only does composting time and treatment have a significant effect on carbon reduction, their interactions also showed it. The average reduction on total carbon of $\mathrm{SR}_{4}$ was higher than other treatments, whereas treatment of $S_{1}$ and $S_{2}$ had the lowest average reduction $(\alpha<0.05)$. This occurrence had created a compatible condition for the growth of microorganism in degrading organic matter.

\section{$3.8 \mathrm{C} / \mathrm{N}$ Ratio}

The $\mathrm{C} / \mathrm{N}$ ratio in compost is one of the markers that can indicate the stabilization of the composting process. Kim et al. [46] explained that the ratio of carbon to nitrogen was used as a index of compost maturity before the compost was applied to the soil [46]. At the beginning of the composting, the $\mathrm{C} / \mathrm{N}$ ratio of $\mathrm{SR}_{1}, \mathrm{SR}_{2}, \mathrm{SR}_{3}, \mathrm{SR}_{4}, \mathrm{SR}_{5}$, and $\mathrm{SR}_{6}$ was $41.73,42.67$, $37.70,36.74,38.63$ and 38.14, respectively (see Figure 7). These values were still regarded effective to start the composting process.

Epstein [19] claimed that the $\mathrm{C} / \mathrm{N}$ ratio of 27 to 30 was the ideal level to initiate the composting process, but the carbon to nitrogen ratio of 22 to 44 was steadfastly presumed effective. Microbes utilize approximately 30 parts of carbon and one part of nitrogen [47]. Subsequently, Li et al. [48] emphasized that the low carbon to nitrogen ratio at the beginning of the composting would generate ammonia and strew odour as a result of nitrogen volatilization [48]. Besides that, the $\mathrm{C} / \mathrm{N}$ ratio surpasses the level of 50:1, which leads to a slow composting process.

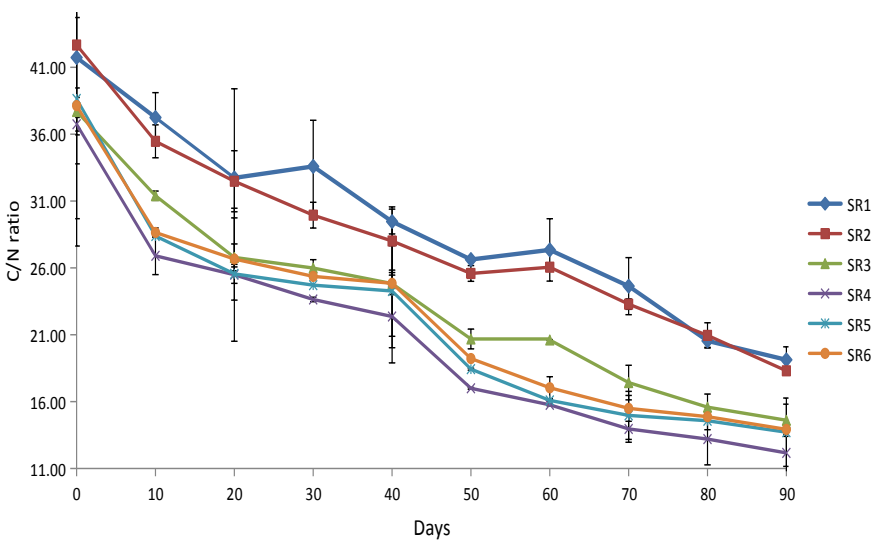

Figure $7 \mathrm{C} / \mathrm{N}$ ratio reduction during the composting process

At the end of the composting, $\mathrm{C} / \mathrm{N}$ ratio of $\mathrm{SR}_{1}$, $\mathrm{SR}_{2}, \mathrm{SR}_{3}, \mathrm{SR}_{4}, \mathrm{SR}_{5}$ and $\mathrm{SR}_{6}$ was 16.39, 16.09, 14.61, 12.17, 13.71 and 13.92, respectively. In general, the $\mathrm{C} / \mathrm{N}$ ratio was observed to be going down on all treatments. The mineralization of organic matter is the cause of reduction in $\mathrm{C} / \mathrm{N}$ ratio. $\mathrm{C} / \mathrm{N}$ ratio values in this study were assumed as mature compost, and the compost could be applied as organic fertilizer on the soil.

Erhart and Burian [49] affirmed that the ideal mature compost had carbon to nitrogen ratio of 15 , but a value of $\mathrm{C} / \mathrm{N}$ ratio below 20 was still safe [49]. The level of $\mathrm{C} / \mathrm{N}$ ratio in this study for all treatments was lower than Vakili et al.'s [15] who had tried the composting of EFB with poultry litter, and had mitigated the $\mathrm{C} / \mathrm{N}$ ratio from 21.91 to 17.6 in 80 days. In addition, Mohammad et al. [12] had attempted the composting of EFB with POME and some the fungal, and had lowered the $\mathrm{C} / \mathrm{N}$ ratio to about 17 within 60 days.

Table 3 Correlation coefficient between composting time with treatment on parameters

\begin{tabular}{|c|c|c|c|c|c|c|c|c|}
\hline \multirow[t]{2}{*}{ Types of Vehicle } & \multirow[t]{2}{*}{ CT } & \multirow[t]{2}{*}{ SR } & \multirow[t]{2}{*}{$\mathbf{R}$} & \multirow[t]{2}{*}{$\mathbf{R}^{2}$} & \multirow[t]{2}{*}{$\mathbf{F}$} & \multicolumn{3}{|c|}{ Coefficient } \\
\hline & & & & & & Constant & $\mathrm{T}$ & SR \\
\hline$M C$ & $-0.448^{* *}$ & $-0.772^{* *}$ & 0.893 & 0.797 & 465.326 & 83.053 & -0.112 & -3.234 \\
\hline TN & $0.797^{* *}$ & $0.388^{* *}$ & 0.887 & 0.787 & 215.524 & 1.149 & 0.11 & 0.094 \\
\hline TOC & $-0.864^{* *}$ & $-0.280 * *$ & 0.908 & 0.824 & 274.080 & 56.353 & -0.173 & -0.941 \\
\hline $\mathrm{C} / \mathrm{N}$ & $-0.847^{* *}$ & $-0.340 * *$ & 0.912 & 0.832 & 289.680 & 40.720 & -0.238 & -1.608 \\
\hline
\end{tabular}

** Significant correlation at the 0.01 level (2-tailed)

CT, SR, MC, TN and TOC are composting time, treatments, moisture content, total nitrogen and total organic carbon 
Table 4 Total of vehicles for each entrance

\begin{tabular}{lllll}
\hline \multicolumn{1}{c}{ Parameters } & \multicolumn{1}{c}{ MC } & \multicolumn{1}{c}{ TN } & \multicolumn{1}{c}{ TOC } & \multicolumn{1}{c}{$\mathbf{C} / \mathbf{N}$} \\
\hline MC & 1.00 & & & \\
TN & $-0.599^{* *}$ & 1.00 & & \\
OC & $0.557^{* *}$ & $-0.846^{* *}$ & 1.00 & \\
C/N & $0.570^{* *}$ & $-0.968^{* *}$ & $0.868^{* *}$ & 1.00 \\
\hline ** Significant correlation at the 0.01 level (2-tailed) \\
MC, TN and TOC are moisture content, total nitrogen and total organic carbon
\end{tabular}

\subsection{Correlation}

The correlation level $(p<0.01)$ between composting time and treatment is depicted by the reliability index (see Table 3). Both treatment and composting time had a negative correlation to moisture content, total organic carbon, and $\mathrm{C} / \mathrm{N}$ ratio. In contrast, total nitrogen showed a positive correlation on composting time and treatment. The reliability index value between composting time and treatment on moisture content, total nitrogen, organic carbon, and $\mathrm{C} / \mathrm{N}$ ratio were $0.89,0.88,0.90$ and 0.91 , respectively. These values denote that there is a strong relationship between composting time and treatment application on the parameters.

The contribution level between treatment and composting time on a decrease of moisture content, organic carbon and $\mathrm{C} / \mathrm{N}$ ratio was $63.52,67.89$ and $69.22 \%$, respectively. Meanwhile, the contribution level between composting time and treatment on increment of nitrogen was about $61.93 \%$. Each parameter exhibited the results of different correlation, and is in Table 4 . $\mathrm{C} / \mathrm{N}$ ratio correlated positive with organic carbon and moisture content, while it correlated negative with total nitrogen

\subsection{CONCLUSION}

The study concluded that the particle size of compost material had a significant effect in improving the composting of empty fruit bunches. The EFB size of 1.5 $\mathrm{cm}$ had exhibited good performance when compared with EFB sizes of $0.5 \mathrm{~cm}$ and $2.5 \mathrm{~cm}$. The addition of biosludge from the pulp and paper industry had been used in the EFB composting as nitrogen source and microbial source to enhance the quality of EFB compost. The best treatment combination was found on SR4. In the thermophilic phase, $\mathrm{SR}_{4}$ had reached an optimal temperature of $60^{\circ} \mathrm{C}$ with the highest concentration of bacteria as much as $33.67 \mathrm{x}$ $10^{10} \mathrm{cfu} / \mathrm{g}$. The mature compost had been achieved in 90 days with a $\mathrm{C} / \mathrm{N}$ ratio of 12.17 .

\section{Acknowledgement}

The author is very grateful to the Pelalawan Amanah Foundation which has supported this research. Thank you wholeheartedly to PT. Riau Andalan Pulp and
Paper which had facilitated this research so that it becomes effective and efficient.

\section{References}

[1] Stichnothe, H., and Schuchardt, F. 2010. Comparison of Different Treatment Options for Palm Oil Production Waste on A Life Cycle Basis. International Journal Life Cycle Assessment. 15: 907-915. DOI: http://dx.doi.org/10.1007/s11367-010-0223-0.

[2] Hayashi, K. 2007. Environmental Impact of Palm Oil Industry in Indonesia. Proceedings of in International Symposium on Eco Topia Science, ISETS07. 646-651.

[3] Darnoko and Sutarta, A. S. 2006. Pabrik Kompos di Pabrik Sawit. Tabloid Sinar Tani. Indonesia.

[4] Badan Pusat Statistik. 2013. Sensus Pertanian 2013. Badan Pusat Statistik Publisher. Indonesia.

[5] Mohammad, N., Alam, Md. Z., Kabashi, N. A., and Ahsan, A. 2012. Effective Composting of Oil Palm Industrial Waste by Filamentous Fungi: A Review. Resources, Conversion and Recycling. 58: 69-78. http://dx.doi.org/10.1016/j.resconre.2011.10.009.

[6] Embrandiri, A., Singh, R. P., Ibrahim, H. M., and Ramli, A. A. 2012. Land Application of Biomass Residue Generated from Palm Oil Processing: Its Potential Benefit and Threats. Environmentalist. $\quad 32$ : 111-117. DOI: http://dx.doi.org/10.1007/s10669-011-9367-0.

[7] Singh, R. P., Ibrahim, M. H., Esa, N., and lliyana, M. S. 2010. Composting of Waste from Palm Oil Mill: A Sustainable Waste management Practice. Rev Environ Sci Biotechnol. 9: 331-334. DOI: http://dx.doi.org/10.1007/s11157-010-9199-2.

[8] Suhaimi, $M$ and Ong, H. K. 2001. Composting Empty Fruit Bunches of Oil Palm. The Food and Fertilizer Technology Center.

[9] Norhasmillah, A. H., Puah, C. W., Ibrahim, N. A., Baharuddin, A. S., and Choo, Y. M. 2013. Life Cycle Inventory of the Commercial Production of Compost Oil Palm Biomass: A Case Study. Environ Dev Sustain. 15(6): 1663-1670. DOI: http://dx.doi.org/10.1007/s10668-013-9457-x.

[10] Baharuddin, A. S., Wakisaka, M., Shirai, Y., Abd-Aziz, S., AbdRahman, N. A., and Hassan, M. A. 2009. Co-Composting of Empty Fruit Bunches and Partially Treated Palm Oil Mill Effluent in Pilot Scale. International Journal of Agricultural Research. 4(2): 69-78

[11] Kananam, W., Suksaroj, T. T., and Suksaroj, C. 2011. Biochemical Changes during Oil Palm (Elaeis Guineensis) Empty Fruit Bunches Composting with Decanter Sludge and Chicken Manure. Science Asia. 37: 17-23. DOI: http://dx.doi.org/10.2306/scienceasia1513-1874.2011.37.017.

[12] Mohammad, N., Alam, Md. Z., and Kabashi, N. A. 2013. Development of Composting Process of Oil Palm Industrial Wastes by Multi-Enzymatic Fungal System. Journal Mater Cycles Waste Management. 15: 348-35. DOI: http://dx.doi.org/10.1007/s10163-013-0125-x.

[13] Razali, W. A. W., Baharuddin, A. S., Talib, A. T., Sulaiman, A. Naim, M. N., Hassan, M. A., and Shirai, Y. 2012. Degradation of Oil Palm Empty Fruit Bunches (OPEFB) Fiber during Composting Process Using In-Vessel Composter. Bioresource. 7(4): 4786-4805 
[14] Thambirajah, J. J., Zulkali, M. D., and Hashim, M. A. 1995 Microbiological and Biochemical Changes during the Composting of Oil Palm Empty-Fruit-Bunches. Effect of Nitrogen Supplementation on the Substrate. Bioresource Technology. 52: 133-144

DOI : http://dx.doi.org/0960-8524/95

[15] Vakili, M., Haque, A. A. M., Hosseini, S. M., and Salamatinia, B. 2012. Evaluation of Maturation and Stability Some Indexes of Mixed Palm Oil Biowaste Composting Process and Poultry Litter. World Applied Sciences Journal. 19(2): 234-240 DOI : http://dx.doi.org/10.1080/03650340.2010.547191

[16] Yahya, A., Sye, C. P., Ishola, T. A., and Suryanto, H. 2010. Effect of Adding Palm Oil Mill Decanter Cake Slurry with Regular Turning Operation on the Compost Process and Quality of Compost from Oil Palm Empty Fruit Bunches. Bioresource Technology. 101: 8736-8741

DOI : http://dx.doi.org/10.1016/j.biortech.2010.05.073

[17] Yeoh, C. Y., Chin, N. L., Tan, C. S., and Ooi, H. S. 2011. Acceleration Effects of Microbial Inoculums on Palm Oil Mill Organic Waste Composting. Compost Science and Utilization. 19(2): 135-142

[18] Bueno, P., Tapias, R., Lopez, F., and Diaz. M. J. 2008. Optimizing Composting Parameters for Nitrogen Conservation in Composting. Bioresource Technology. 99: 5069

[19] Epstein, E. 2011. Industrial Composting: Environmental Engineering and Facilities Management. CRC Press, New York

[20] Asia Pacific Resources International . 2012. Riau Fiber and Mill Overview. APRIL Press. Indonesia

[21] Luo, W., Chen, T. B., Zheng, G. D., Gao, D., Zhang, Y. A., and Gao, W. 2008. Effect of Moisture Adjustments on Vertical Temperature Distribution during Forced-Aeration Static-Pile Composting of Sewage Sludge. Resources, Conservation and Recycling. 52: 635-642

DOl : http://dx.doi.org/10.1016/j.resconrec.2007.08.004

[22] APHA. 2005. Standard Methods for Examination Water and Wastewater, $21^{\text {th }}$ Edition, American Public and Health Association, Washington, $D, C$.

[23] Ahmad, M. N., Mokhtar, M. N., Baharuddin, A. S., Hock, L. S., Ali, S. R. A., Abd-Aziz, S., Rahman, N. A. A., and Hassan, M. A. 2011. Changes in Physicochemical and Microbial Community during Co-Composting of Oil Palm Frond with Palm Oil Effluent Anaerobic Sludge. Bioresource. 6(4): 47624780

[24] Okwute., Ojonoma, L., and Nnennaya, I. 2007. The Environmental Impact of Palm Oil Mill Effluent (POME) on Some Physico-Chemical Parameters and Total Aerobic Bioload of Soil at A Dump Site In Anyigba, Kogi State, Nigeria. African Journal of Agricultural Research. 2(12): 656662

[25] Haug, R. T. 1993. The Practical Handbook of Compost Engineering, Lewis Publisher, Boca Raton

[26] Khalil, A. I., Hassouna, M. S., El-Ashqar, H. M. A., and Fawzi, M. 2011. Changes in Physical, Chemical and Microbial Parameters during the Composting of Municipal Sewage Sludge. World Journal Microbiological Biotechnology. 27: 2359-2369. DOI: http://dx.doi.org/10.1007/s1 1274-011 and $\mathrm{H}$ 2001. Effect of Bulking Agent on the Reduction of $\mathrm{NH}_{3}$ Emissions during Thermophilic Composting of Night-Soil Sludge. Waste Management Resources. 19(4): 301-307

[27] Mokhtari, M., Nikaeen, M., Amin, M. M., Bina, B., and Hasanzadeh, A. 2011. Evaluation of Stability Parameters in In-Vessel Composting of Municipal Solid Waste. Iran Journal Environment Health Science Engineering. 8(4): 325-332

[28] Caceres, R., Flotats, X., and Marfa, O. 2006. Changes in the Chemical and Physicochemical Properties of the Solid Fraction of Cattle Slurry during Composting Using Different Aeration Strategies. Waste Management. 26: 1081-1091. DOI : http://dx.doi.org/10.1016/j.wasman.2005.06.013.

[29] Gajalakshmi, S., and Abbasi, S. A. 2008. Solid Waste Management by Composting: State of the Art. Critical Review in Environmental Science and Technology. 38: 311 400. DOI: http://dx.doi.org/10.1080/10643380701413633.
[30] Raclavska, H., Juchelkova, D., Skrobankova, H., Wiltowski, T., and Campe, A. 2011. Conditions for Energy Generation as an Alternative Approach to Compost Utilization. Environmental Technology. 32(4): 407-417. DOI: http://dx.doi.org/10.1080/09593330.2010.501089.

[31] Sundberg, C., and Jonsson, H. 2008. Higher pH and Faster Decomposition in Biowaste Composting by Increased Aeration. Waste Management. 28: 518-526. DOI: http://dx.doi.org/10.1016/j.wasman.2007.01.011.

[32] Ryckeboer, J., Mergaert, J., Vaes, K., Klammer, S., De Clercq, D., Coosemans, J., Insam, H., and Swings, J. 2003. A Survey of Bacteria and Fungi Occurring during Composting and Self-heating Process. Annals of Microbiology. 53(4): 349410.

[33] Tanpanich, S., Chindachia, R., and Duriyaprapan, S. 2009. Rate of Composting and Quality of Compost under Different Passively Aerated Composting. Supplement. 37: 153-161

[34] Madan, S., Bhatia, A., Rajpal, A., and Kazmi, A. A. 2012. Maturity Assessment of Rotary Drum and Windrow Composts in Terms of Germination Index and Enzymatic Activities. International Journal of Applied Science and Engineering Research. 1(3): 415-426. http://dx.doi.org/10.6088/ijaser.0020101042.

[35] Liang, C., Das, K. C., and McClendon, R. W. 2003. The Influence of Temperature and Moisture Contents Regimes on the Aerobic Microbial Activity of a Biosolids Composting Blend. Bioresource Technology. 86: 131-137. DOI: http://dx.doi.org/s0960-8524(02)00153-0.

[36] Mohee, R., and Mudhoo, A. 2005. Analysis of the Physical Properties of an in-Vessel Composting Matrix. Powder Technology. 155: 92-99. http://dx.doi.org/10.1016/j.powtec.2005.05.051.

[37] Hong, N., Chen, J., Zhang, X., and Chen, T. 2013. Effect of Turning on Moisture Content in Sewage Sludge Composting. Advanced Materials Research.

[38] lyengar, S. R., and Bhave, P. P. 2006. In-Vessel Composting of Household Waste. Waste Management. 26: 1070-1080. DOI: http://dx.doi.org/10.1016/j.wasman.2005.06.011

[39] Oviasogie, P. O., Aisueni, N. O., and Brown, G. E. 2010. Oil Palm Composted Biomass: A Review of the Preparation, Utilization, Handling and Storage. African Journal of Agricultural Research. 5(13): 1553-1571. DOI: http://dx.doi.org/10.5897/AJAR09.016.

[40] Rasapoor, M., Nasrabadi, T., Kamali, M., and Hoveidi, H. 2009. The Effects of Aeration Rate on Generated Compost Quality, Using Aerated Static Pile Method. Waste Management. 29: 570-573. DOl: http://dx.doi.org/10.1016/j.wasman.2008.04.012.

[41] Sommer, S. G. 2001. Effect of Composting on Nutrient Loss and Nitrogen Availability of Cattle Deep Litter. European Journal of Agronomy. 14: 123-133. DOI: http://dx.doi.org/S1161-0301 (00)00087-3.

[42] Solano, M. L., Iriarte, F., and Negro, M. J. 2001. Performance Characteristic of Three Aeration System in the Composting of Sheep Manure and Straw. Journal Agriculture Engineering Resource. 79(3): 317-329. http://dx.doi.org/10.1006/jaer.2001.0703.

[43] Kraus, H. T., and Warren, S. L. 2000. Performance of Turkey Litter Compost as Slow-Release Fertilizer in Containerized Plant Production. Hort-Science. 35: 19

[44] Barrington, S., Choiniere, D., Trigui, M., and Knight, W. 2003. Compost Convective Airflow under Passive Aeration. Bioresource Technology. 86: 259-266. DOI: http://dx.doi.org/S0960-8524(02)00155-4.

[45] Kim, J. D. and Park, J. S. In, B. H., Kim, D., and Namkoong, W. 2008. Evaluation of Pilot-Scale In-Vessel Composting for Food Waste Treatment. Journal of Hazardous Materials. 154: 272-277. http://dx.doi.org/10.1016/j.jhazmat.2007.10.023.

[46] Martin, A. M. 1999. Bioconversion of Waste Materials to Industrial Products. New York. Elsevier Publishers.

[47] Li, X., Zhang, R., and Pang, Y. 2008. Characteristics of Dairy Manure Composting with Rice Straw. Bioresource 
Technology.

99: $\quad 359-36$.

http://dx.doi.org/10.1016/j.biortech.2006.12.009.

DOI: Suppressiveness of Austrian Biowaste Compost. Compost Science Utilization. 5: 15. 